\title{
Fabrication Of Enhanced Solar Still with Power Generation
}

\author{
Mr.M.Jayaraj ${ }^{1}$, Mr.V.P.Surseh Kumar², Mr.J.Jayasuriyaa Skandhan ${ }^{3}$, \\ Mr.G.Giftson Jebadurai ${ }^{4}$, Mr.M.Ajith Kumar ${ }^{5}$ \\ ${ }^{1,2}$ (Assistant Professor, Mechanical, PA college of engineering and Technology, India) \\ 3, 4, 5 (Student, Mechanical, PA college of engineering and Technology, India)
}

\begin{abstract}
In this project, the process of fabrication of enhanced solar still with power generation was taken down. A solar still distills water using the radiation of the Sun to evaporate the water and then it cools and collects the pure water. The main objective of our project is to purify the saline water into drinking water. Additionally, turbine and dynamo were fixed to generate the electricity and then store it in a battery. This equipment can also be used in home and mineral water industries. This equipment will play an important role among the human life, as the water is the main source of human being. For this project, the components such as copper tube, aluminum sheet, plywood, gutter, valve, wedge box (solar still), glass plate, battery, PVC pipe, lateral pipe, turbine and dynamo were utilized.
\end{abstract}

Keyword: Solar still, saline water, wedge box, copper tube.

\section{Introduction}

Most of our earth surface is covered by water, but only less than $1 \%$ of total available water is fresh water which is mostly found in lakes, rivers and underground. About one-third of that potential fresh water can only be used for human needs due to mixed factors. Approximately 1.1 billion people in this world have inadequate access to safe drinking water. In the world, there are 26 countries which do not have enough water to maintain agriculture and economic developments. At least $80 \%$ of arid and semi-arid countries have serious periodic droughts. Water to be cleaned is poured into the still. The glass cover allows the solar radiation to pass into the still, which is mostly absorbed by the aluminum sheet base. The water begins to heat up and then the moisture content of the air trapped between the water surface and the glass cover increases. The heated water vapor evaporates from the basin and condenses on the inside surface of the glass cover. In this process, the salts and microbes that were present in the original water are left behind. Condensed water trickles down over the inclined glass cover to an interior collection trough and out to a storage bottle [1].A variation in the glass cover angle of inclination should affect the dynamics of condensation and movement of the water along the inner surface of the cover. Having observed the performance of stills with different angles of inclination, it can be partially established that the optimal still cover inclination for Makurdi location is higher than $15^{\circ}$ as indicated by the characteristic volume/efficiency versus inclination of cover trend lines. It is a partial conclusion because a more rigorous work with larger angles of inclination. However, the observation from this study has effectively erased the existing tendency of using low angles and obtaining reasonably acceptable results due primarily to the climatic conditions[2]. The paper deals with the design and fabrication of the solar water heater to use unconventional energy as a means to obtained hot water for domestic applications, at comparatively low cost and high capacity by the use of material like plastic lateral tubes, HDPE pipe, old glass wool, thermocol, plastic drum, G.I. sheet collect or boxes . Replacing the material as copper tube, stainless steel water tank, thick costly PUF insulations, toughened glass etc. further the "Pebbles" are used as a medium of heat storage so as to increasing the capacity of solar water heater instead of using an electric heater instead of using an electric heater as in days water heater present in the market [3].The principle of power generation is same as that of the hydro power plant. The kinetic energy of water is utilized to run the turbines which in turn run the dynamo. The energy of water is utilized for power generation. Once when the water flows from the top, the water rushes and flows downward due to gravitational force. This high pressure water falls on the blades of the turbine and thus produces a mechanical motion. The turbine is directly coupled with dynamo. The mechanical energy of the turbine is thus converted into electrical energy by the dynamo. Here the power generated by the dynamo is stored in the battery for the further use. The range of the battery is chose based on the power produced [4].

\section{Methodology Of The Project}

This chapter discusses the method used to design a solar water purifier with power generation. In primary set up, the copper tube and aluminum sheet are arranged to pre-heat the water. In secondary set up, the wedge shaped box known as solar still is built to filter the brackish water. Additionally, the turbine and dynamo set up is constructed to generate the electric power. 


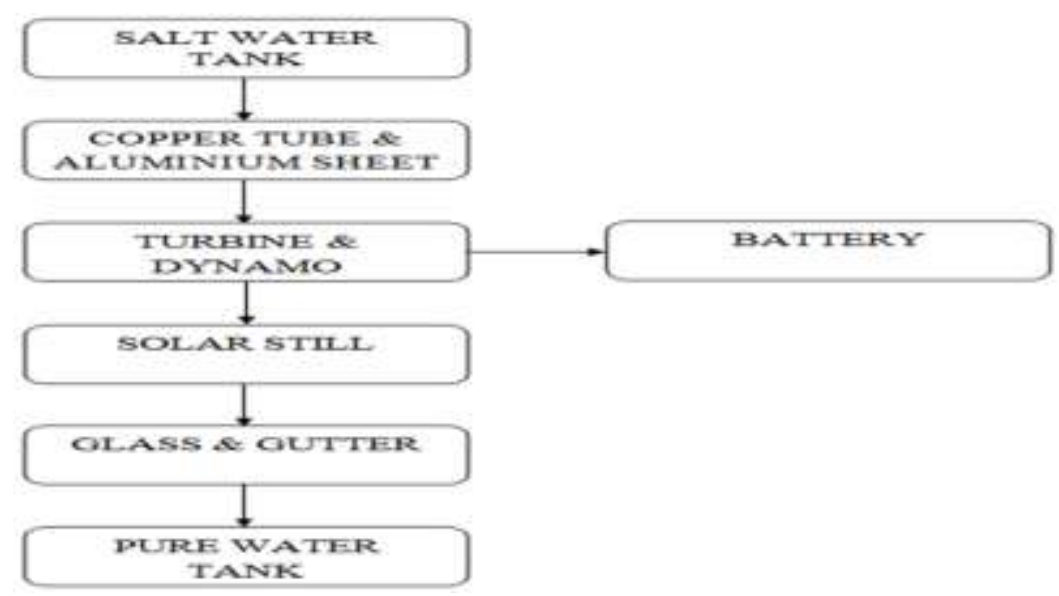

Fig: 1 Methodology of the Project

\subsection{Solar Still}

\section{Modeling Of The Project}

Base $=600 \times 450 \mathrm{~mm}^{2}$

Height $(\mathrm{h} 1)=220 \mathrm{~mm}$

Height $(\mathrm{h} 2)=130 \mathrm{~mm}$

Angle $(\theta)=11^{\circ}$

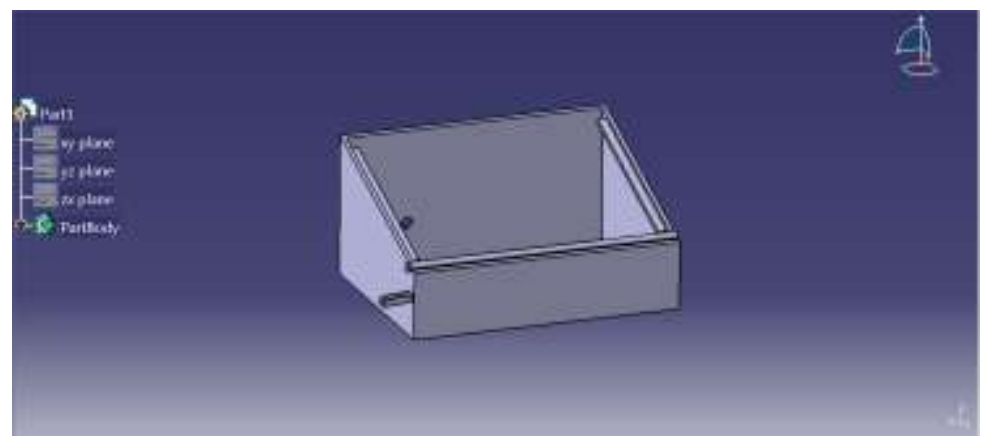

\subsection{Turbine \& Dynamo}

Fig:2 CATIA model of Solar still

Base $=20 \times 110 \mathrm{~mm}^{2}$

Height $(\mathrm{h} 1)=75 \mathrm{~mm}$

Height $(\mathrm{h} 2)=55 \mathrm{~mm}$



Fig: 3 CATIA model of Turbine \& dynamo 


\subsection{Copper Tube Setup}

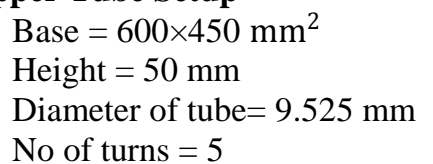

No of turns $=5$

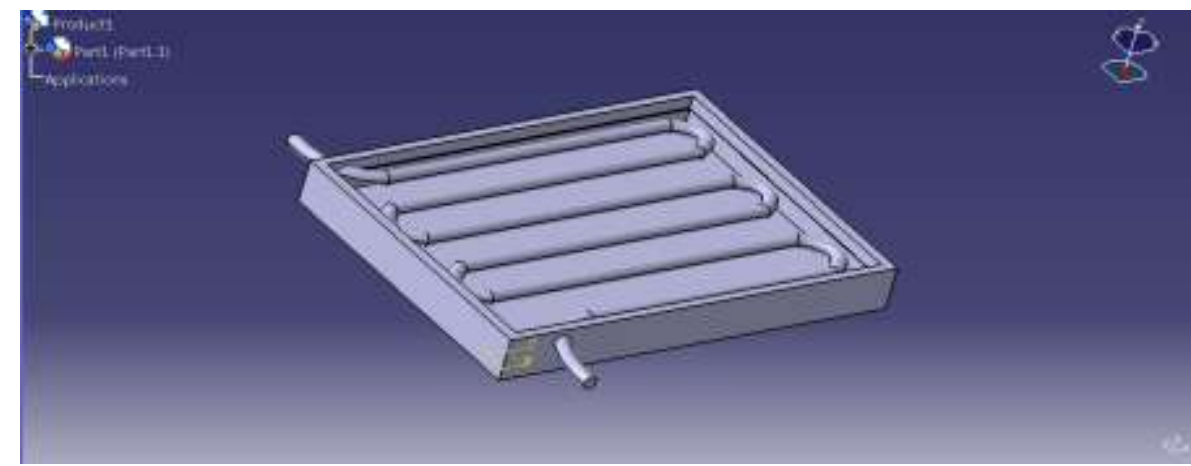

Fig: 4 CATIA model of Copper tube arrangement

\subsection{Specifications of Components}

Table: 1 Specification of Components

\begin{tabular}{|l|l|}
\hline COMPONENTS & SPECIFICATIONS \\
\hline Copper Tube & Diameter $=3 / 8$ inches, $12 \mathrm{ft}$ \\
\hline Aluminum Sheet & Thickness $=1 \mathrm{~mm}, 2 \times 4.5 \mathrm{ft}$ \\
\hline Plywood & Thickness $=1$ inch, 14 sq. $\mathrm{ft}$ \\
\hline Gutter & Length $=2.5 \mathrm{ft}$ \\
\hline Dynamo & $12 \mathrm{v}, 100 \mathrm{rpm}$ \\
\hline Glass plate & Thickness $=4 \mathrm{~mm}, 2 \times 2 \mathrm{ft}$ \\
\hline Lateral Pipe & Diameter $=12 \mathrm{~mm}$, length $=4$ meter \\
\hline PVC pipe & $\begin{array}{l}\text { Diameter }=3 / 4 \text { inch, length }=3 \mathrm{ft}, \\
\text { Diameter }=1 \text { inch, length }=1 \mathrm{ft}\end{array}$ \\
\hline Battery & 4v DC \\
\hline
\end{tabular}

\section{Fabrication And Working Procedure}

The wedge shaped wooden box known as a solar still is made of plywood. The top surface is covered with a glass plate. The bottom surface is covered with the aluminum sheet to heat the water through the sunlight. One end of the glass plate is fitted inside the PVC pipe for collecting the water droplets. The gutter is placed parallel below the PVC pipe in order to collect the pure water from the PVC pipe falling through small holes. The gutter is placed in an inclined manner to pass and collect the obtained pure water in the external tank. The copper tube is arranged in the form of zigzag above the aluminum sheet. Then this aluminum sheet and copper tube arrangement is mounted on the wooden box like arrangement. This arrangement is placed in the inclination of about $11 \square$ and directly placed above the solar still. The salt water initially passed through the copper pipe. Then the salt water is heated by solar radiation in copper pipe. Here copper pipe is placed above the aluminum sheet to increase the optimum temperature. The pre-heated water enters into a wedge shape solar still. Before that water flow through a gate valve which allow the water into still. The flow of water tends to rotate the turbine in order to rotate the dynamo to generate the power. Then the generated power is stored in the external battery. Water again heats up to vaporize inside the solar still. The vaporized steam condensed on the glass in the form of water droplets. Then the condensed water droplets fall in the gutter placed under the glass and then it is collected in the tank as pure water.



Fig: 5 Solar Still with Power Generation 


\section{Result And Discussion}

5.1 Temperature of Water inside Solar Still (Without Copper Tube Arrangement)

The water is filled inside the solar still at 09:00 AM. The temperature of water $\left[\mathrm{T}_{1}\right]$ varying inside the solar still without the copper tube arrangement for every hour from 10:00 AM to 04:00 PM were noted in the tabulation below,

Table: 2 Times and Temperature $\left[\mathrm{T}_{1}\right]$

\begin{tabular}{|l|l|}
\hline $\begin{array}{l}\text { TIME } \\
\text { (hours) }\end{array}$ & $\begin{array}{l}\text { TEMPERATURE OF WATER }\left[\mathbf{T}_{\mathbf{1}}\right] \\
(\square \mathbf{C})\end{array}$ \\
\hline 10:00 AM & 27 \\
\hline $11: 00 \mathrm{AM}$ & 36 \\
\hline 12:00 AM & 43 \\
\hline $01: 00 \mathrm{PM}$ & 60 \\
\hline $02: 00 \mathrm{PM}$ & 53 \\
\hline $03: 00 \mathrm{PM}$ & 46 \\
\hline $04: 00 \mathrm{PM}$ & 39 \\
\hline
\end{tabular}

\subsection{Temperature of Water inside Solar Still (With Copper Tube Arrangement)}

The water is filled inside the copper tube at 09:00 AM and then passed to the solar still with the help of lateral pipe and valve arrangement. The temperature of water $\left[\mathrm{T}_{1}\right]$ varying inside the solar still with the copper tube arrangement for every hour from 10:00 AM to 04:00 PM were noted in the tabulation below,

Table:3 Time and Temperature $\left[\mathrm{T}_{2}\right]$

\begin{tabular}{|l|l|}
\hline TIME (hours) & $\begin{array}{l}\text { TEMPERATURE OF WATER [ } \\
(\square \mathbf{C} \text { ) }\end{array}$ \\
\hline 10:00 AM & 29 \\
\hline 11:00 AM & 39 \\
\hline 12:00 AM & 47 \\
\hline 01:00 PM & 65 \\
\hline 02:00 PM & 57 \\
\hline 03:00 PM & 49 \\
\hline 04:00 PM & 41 \\
\hline
\end{tabular}

\subsection{Temperature of Water in Copper Tube Arrangement}

The water is filled inside the copper tube at 09:00 AM. The temperature of water passed out from the copper tube arrangement alone for every hour from 10:00 AM to 04:00 PM were noted in the tabulation below,

\begin{tabular}{l} 
Table:4 Time and Temperature $\left[\mathrm{T}_{3}\right]$ \\
\begin{tabular}{|l|l|}
\hline $\begin{array}{l}\text { TIME } \\
\text { (hours) }\end{array}$ & $\begin{array}{l}\text { TEMPERATURE OF WATER }\left[\mathbf{T}_{3}\right] \\
(\square \mathbf{C})\end{array}$ \\
\hline 10:00 AM & 30 \\
\hline 11:00 AM & 41 \\
\hline 12:00 AM & 49 \\
\hline $01: 00 \mathrm{PM}$ & 68 \\
\hline $02: 00 \mathrm{PM}$ & 59 \\
\hline $03: 00 \mathrm{PM}$ & 51 \\
\hline $04: 00 \mathrm{PM}$ & 42 \\
\hline
\end{tabular} \\
\hline
\end{tabular}

The maximum temperature achieved in this copper tube set up alone is minimized while passing to the solar still due to the flow of water through the turbine set up.

\subsection{Graphical Representation}

The graphical representation between the temperature of water inside the solar still with and without copper tube arrangement is represented as below,

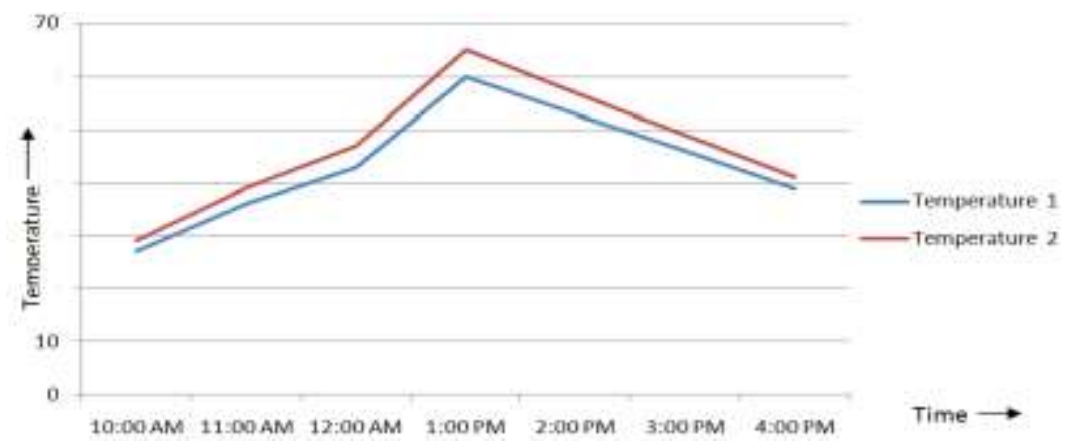


Fig: 5 Hourly range of Temperature variation

\section{Conclusion}

The solar still, in our project is enhanced to the highest possible outcome. It is achieved by using aluminum sheet and the primary arrangement of copper tube for pre-heating the water. Solar energy could be used for desalination of water rather than any other energy resource as solar energy is available in abundance. In conventional water treatment process the fuel consumption is more. But in case of a solar powered desalination system, sources of fuel are limited. With the proper solar radiation data collection and modeling after a few months, our project is carried out.

From the graph 9.1, the evaporation is maximum at the time period of 12:00 am to 02:00 pm. The maximum temperature achieved is $65^{\circ} \mathrm{C}$ at $1: 00 \mathrm{pm}$ and then the temperature decreases simultaneously.

Further, we have decided to enhance our project by utilizing the power generated from the turbine and dynamo setup to run any vacuum device or vacuum pump in order to create a vacuum inside the solar still. Decreasing the pressure inside the still will decrease the boiling temperature of the water. Thus, it may further enhance the output of our project.

\section{References}

[1]. Alpesh Mehta, Alpha Vyas, Nitin Bodar and Dharmesh Lathiya, Design of Solar Distillation System, International Journal of Advanced Science and Technology,Vol.29, 2011, 67-73.

[2]. Edeoja, Alex Okibe and Unom, Fadoo, Investigation of the Effect of Angle of Cover Inclination on the Yield Of A Single Basin Solar Still Under Makurdi Climate, The International Journal Of Engineering And Science , 2, 2013,. 131-138.

[3]. Mangesh.A. Pachkawade, Pritam.R.Nimkar and Balu.K.Chavhan, Design and Fabrication of Low Cost Solar Water Heater, International Journal of Emerging Trends in Engineering and Development, Vol. 6, 2013,465-481.

[4]. U.Someshwar Dutta, S.Arun prabu, M.Karthik and T.Ramkumar, Waterfall Power Generation System, International Journal of Innovations in Engineering and Technology ,3,2013, 131-133

[5]. M.A.S.Malik, G.N.Tiwari, A.Kumar and M.S. Sodha. "Solar Distillation", International Journal of Mechanical Engineering and Technology, 1982.

[6]. Kumar.S and Tiwari.G.N, 1996, "Estimation of Convective Mass Transfer in Solar Distillation System," Solar Energy, 57, 459464.

[7]. Tiwari.A and Tiwari.G.N, Effect of Water Depths on Heat and Mass Transfer in a Passive Solar Still: in Summer Climatic Condition, Elsevier, Desalination, 195, 2005, 78-94.

[8]. Nikhil Singh, Performance Analysis of Single Slope Solar Stills at Different Inclination Angles: an Indoor Simulation, International Journal of Current Engineering and Technology, 3(2), 2013, 677-684.

[9]. V. Velmurugan, K. J. N. Kumar, T. N. Haq \& K. Srithar, Performance analysis in stepped solar still for effluent desalination, Energy, 34, 2009, $1179-1186$.

[10]. M. A. Samee, U. K. Mirza, T. Majeed \& N. Ahmad, Design and performance of a simple single basin solar still, Renewable and Sustainable Energy Reviews, 11, 2007, $543-549$. 